\title{
STRATEGI PEMBENTUKAN LINGKUNGAN BERBAHASA ARAB DI MADRASAH ALIYAH
}

\author{
Rini Astuti, Akla, Albarra Sarbaini \\ Institut Agama Islam Negeri Metro \\ email: rinixla5@gmail.com
}

\begin{abstract}
This study aimed to analyze models of the Arabic language environment formation to increase the ability of language learners in Islamic Senior High School. This research method was qualitative. The research was conducted at Islamic Senior High School 1 Metro. Research respondents were 245 students of boarding Islamic Senior High School that consisted of 170 females and 73 males. The data collection method used participant observation instruments and interviews. Both of these instruments were used to get data about the models of the Arabic language environment formation to increase the language skills of students in Islamic Senior High School. Steps of Data analysis techniques were collecting data, reducing data, presenting data, and making a conclusion. The results showed that the model of the formation of the Arabic language environment consisted of the visual environment, audio environment, and the audiovisual environment. This model was able to overcome the difficulties of students in acquiring Arabic. This model of the Arabic language environment provides direct and natural Arabic mastery. Qualitative analysis results showed that the Arabic environment was able to increase students' language skills of Islamic Senior High School.
\end{abstract}

Keywords: Arabic Learning; Language Environment; Language Skills.

\begin{abstract}
Abstrak
Penelitian ini bertujuan menganalisis model-model pembentukan lingkungan berbahasa Arab untuk meningkatkan kemampuan berbahasa siswa Madrasah Aliyah. Metode penelitian ini adalah kualitatif. Penelitian dilakukan di Madrasah Aliyah Negeri 1 Metro. Responden penelitian adalah siswa Madrasah Aliyah yang tinggal di asrama. Jumlah responden penelitian sebanyak 243 orang terdiri dari siswa perempuan 170 dan siswa laki-laki 73 orang. Metode pengumpulan data dilakukan dengan menggunakan instrumen observasi partisipan dan wawancara mendalam. Kedua instrumen ini digunakan untuk mendapatkan data tentang model-model pembentukan lingkungan berbahasa
\end{abstract}


Arab untuk meningkatkan kemampuan berbahasa siswa Madrasah Aliyah. Teknik analisis data dilakukan dengan tahapan mengumpulkan data, mereduksi data, menyajikan data dan membuat kesimpulan. Hasil penelitian menunjukan bahwa model-model pembentukan lingkungan berbahasa Arab terdiri dari lingkungan pandang, lingkungan dengar dan lingkungan pandang dengar. Model-model ini telah mampu mengatasi kesulitan siswa dalam pemerolehan bahasa Arab. Model lingkungan bahasa Arab bentukan ini memberikan penguasaan bahasa Arab secara langsung dan alami. Pembelajaran bahasa Arab yang berlangsung secara optimal di dalam lingkungan berbahasa mampu melatih kemahiran siswa dalam semua aspek kebahasaan. Hasil analisis kualitatif menunjukkan bahwa lingkungan berbahasa Arab mampu meningkatkan kemampuan berbahasa siswa Madrasah Aliyah.

Kata Kunci: Pembelajaran Bahasa Arab, Lingkungan Berbahasa, Kemahiran Berbahasa.

\section{A. Pendahuluan}

Sistem pengajaran bahasa Arab di Madrasah Aliyah semakin dinamis dan variatif sesuai dengan perkembangan pengetahuan manusia. Salah satu strategi yang dapat menunjang tercapainya tujuan pembelajaran bahasa yaitu dengan menciptakan lingkungan berbahasa. Lingkungan berbahasa dengan segala kegiatan kebahasaan yang terdapat di dalamnya dan dilaksanakan siswa secara baik dapat mendukung proses penguasaan bahasa. ${ }^{1}$ Lingkungan memiliki peran besar terhadap pemerolehan kemahiran berbicara siswa. Lingkungan berbahasa yang diorganisir secara maksimal dan terprogram sejalan dengan tujuan pengajaran dapat membantu keberhasilan siswa dalam mencapai tujuan. Kesulitan-kesulitan yang dialami siswa dalam pemerolehan kemahiran berbicara disebabkan oleh lingkungan berbahasa yang tidak kondusif. ${ }^{2}$ Lingkungan berbahasa yang optimal dapat mempermudah siswa dalam menguasai kemahiran berbahasa. Kemudahan yang dirasakan siswa selain karena lingkungan berbahasa menerapkan teori secara langsung, siswa bahasa juga dapat secara langsung mendengar, melihat, mengucapkan dan menirukan apa yang didengar, dilihat dan dicontohkan. Dengan cara ini tujuan pembelajaran bahasa dapat tercapai dengan baik.

Penelitian A. Hidayat mengkaji tentang pelibatan lingkungan berbahasa dalam proses pembelajaran bahasa Arab. Lingkungan belajar yang berupa penerapan strategi pembelajaran, media pembelajaran dan organisir kelas yang dilakukan pengajar. Keberadaan lingkungan berbahasa Arab akan

\footnotetext{
${ }^{1}$ Yenti Juniarti dan Eva Gustiana, "Pengembangan Sumber Belajar Bermain Berbasis Mobile Learning," Jurnal Pendidikan Edutama 6, no. 1 (2019): 37-42, https://doi.org/10.30734/jpe.v6i1.289.

${ }^{2}$ Nur Habibah, "Lingkungan Artifisial dalam Pembelajaran Bahasa Arab," Arabiyat : Jurnal Pendidikan Bahasa Arab dan Kebahasaaraban 3, no. 2 (2016): 173-96, https://doi.org/10.15408/a.v3i2.4038.
} 
membentuk gradasi dan konteks pembelajaran yang ideal. Apabila lingkungan berbahasa Arab kondusif, maka proses pembelajaran juga akan berlangsung kondusif. ${ }^{3}$ Penelitian Maspalah menjelaskan bahwa lingkungan audio dapat memberikan pengaruh terhadap pemerolehan bahasa dan kemahiran berbicara. Lingkungan audio yang diperdengarkan kepada siswa dengan menggunakan bahasa sasaran membantu siswa dapat melafalkan bahasa sasaran dengan baik. ${ }^{4}$ Lingkungan berbahasa sebagai sarana dalam pengembangan bahasa Arab dengan memberikan stimulus respon keaktifan berbahasa. Dengan adanya lingkungan bahasa diharapkan dapat mengembangkan potensi siswa dalam berbahasa Arab. ${ }^{5}$

Penelitian terdahulu mengkaji dua isu utama. Pertama, penelitian yang mengkaji lingkungan berbahasa hanya pada proses pembelajaran. Penerapan lingkungan berbahasa hanya ketika proses pembelajaran bahasa Arab berlangsung di kelas. Kedua, penelitian yang mengkaji tentang lingkungan berbahasa dengar saja. Lingkungan bahasa dengar adalah penggunaan bahasa sasaran dalam setiap informasi audio. Lingkungan bahasa menjadi wadah untuk menginterpretasikan pembelajaran, dengan adanya lingkungan bahasa pembelajaran tidak hanya berada di kelas, sehingga memberikan banyak ruang dan kesempatan siswa untuk melatih kemampuan bahasanya.

Penelitian ini akan mengkaji tentang strategi pembentukan lingkungan berbahasa Arab baik di dalam proses pembelajaran maupun di luar proses pembelajaran. Lingkungan bahasa merupakan fasilitas bagi siswa dalam memperoleh pengetahuan bahasa. Lingkungan bahasa berkaitan dengan seluruh aspek yang mendukung pada proses pemerolehan bahasa, baik itu dari tempat, dari kondisi alam, dan perilaku manusia, semua itu sangat penting dalam mewujudkan keterampilan berbicara untuk siswa bahasa Arab. Sejalan dengan tujuan tersebut pertanyaan dirumuskan: Bagaimana model-model pembentukan lingkungan berbahasa untuk meningkatkan kemampuan berbahasa siswa Madrasah Aliyah? Jawaban atas pertanyaan ini dapat memberikan kontribusi kepada pengajar bahasa Arab dalam melakukan proses pembelajaran bahasa. Selain itu penelitian ini juga dapat menjadi dasar bagi pengambil kebijakan dalam pengembangan lingkungan berbahasa Arab.

${ }^{3}$ A. Hidayat, "Bi'ah Lughowiyah (Lingkungan Berbahasa) Dan Pemerolehan Bahasa (Tinjauan Tentang Urgensi Lingkungan Berbahasa Dalam Pemerolehan Bahasa)," An-Nida' 37, no. 1 (2012): 35-44, http://ejournal.uin-suska.ac.id/index.php/Anida/article/view/311.

${ }^{4}$ Maspalah Maspalah, "Metode Audiolingual Dalam Pembelajaran Bahasa Arab Untuk Meningkatkan Kemampuan Berbicara," Jurnal Pendidikan Bahasa Dan Sastra 15, no. 1 (2015): 68-78, https://doi.org/10.17509/bs_jpbsp.v15i1.800.

${ }^{5}$ M. Rizal Rizqi, “Resonansi Bi'ah Lughawiyyah Dalam Meningkatkan Akuisisi Bahasa Arab," Dar-EL-IImi : Jurnal Studi Keagamaan, Pendidikan Dan Humaniora 4, no. 2 (2017): 89-105, http://e-jurnal.unisda.ac.id/index.php/dar/article/view/654. 
Penelitian ini didasarkan pada empat asumsi utama. Pertama, lingkungan berbahasa sangat mendukung proses penguasaan bahasa Arab. Lingkungan berbahasa terbukti memainkan peran penting dalam menunjang efektivitas pembelajaran bahasa Arab di lembaga pendidikan. Kedua lingkungan berbahasa menjadi sarana pemberdayagunaan bahasa Arab secara komunikatif melalui pelaksanaan kegiatan muhadatsah yaumiyah, muhadharah, debat dan seminar bahasa Arab. Ketiga lingkungan berbahasa memperkuat pembelajaran bahasa Arab yang telah diperoleh siswa di dalam kelas, siswa memiliki kesempatan untuk mempraktekkan kemampuan berbahasa Arab yang dimilikinya. Keempat lingkungan berbahasa mengoptimalkan kreativitas dan aktivitas bahasa Arab secara sinergis antara teori dan praktek dalam suasana informal dan tidak membosankan. Ringkasnya, tujuan penciptaan lingkungan berbahasa Arab adalah meningkatkan kemampuan dan kemahiran siswa dalam berbahasa Arab secara aktif, sehingga proses pembelajaran bahasa Arab menjadi lebih dinamis, efektif dan variatif. ${ }^{6}$

\section{B. Studi Literatur}

\section{Konseptual Pemerolehan Bahasa}

Pemerolehan bahasa adalah proses seseorang dalam mendapatkan sebuah kemampuan, pemahaman dan penggunaan bahasa sebagai alat komunikasi, pemerolehan bahasa disebut sebagai proses alami yang tidak disadari oleh seseorang, proses ini berlangsung saat seseorang itu memperoleh bahasa pertamanya atau bahasa ibu. ${ }^{7}$ Pemerolehan bahasa merupakan proses bawah sadar, atau proses mental yang mengarah pada kompetensi berbahasa dan penguasaan tata bahasa. ${ }^{8}$ Pemerolehan bahasa terjadi secara alami tanpa disadari manusia, proses ini berlangsung ketika seseorang berinteraksi langsung dengan orang-orang di lingkungan sekitarnya,bahasanya pun tanpa memperhatikan teori-teori bahasa akan

\footnotetext{
${ }^{6}$ Noza Aflisia dan Partomuan Harahap, “Eksistensi Bi'ah Lughawiyah Sebagai Media Berbahasa Arab Dalam Meningkatkan Kemampuan Muhadatsah Mahasiswa Prodi Pendidikan Bahasa Arab IAIN Curup," Lisanul' Arab: Journal of Arabic Learning and Teaching 8, no. 1 (2019): 40-55, https://journal.unnes.ac.id/sju/index.php/laa/article/view/32545.

${ }^{7}$ Husnuzziadatul Khairi, "Karakteristik Perkembangan Anak Usia Dini Dari 0-6 Tahun," Jurnal Warna 2, no. 2 (2018): 15-28, https://ejournal.iaiig.ac.id/index.php/warna/article/view/87.

${ }^{8}$ Siti Salamah, "Studi Ringkas Pemerolehan Bahasa Pada Anak," BAHASTRA 33, no. 2 (2015), http://journal.uad.ac.id/index.php/BAHASTRA/article/view/2636.
} 
tetapi lebih fokus pada penggunaannya dalam berkomunikasi. ${ }^{9}$ Strategi alamiah dan praktis yang dialami siswa dalam pemerolehan bahasa pertama, dapat diterapkan dengan cara banyak menyimak dan menirukan bahasa target. Proses ini disetting secara formal, yaitu dengan pembelajaran bahasa di kelas, adanya guru, pembelajar, materi, tujuan, kegiatan belajar mengajar, dan evaluasi yang dilakukan untuk mengembangkan kemampuan bahasa. ${ }^{10}$

Tahap pemerolehan bahasa kedua melalui proses pembelajaran dengan optimalisasi lingkungan pembelajaran bahasa kedua akan distimulasi oleh berbagai faktor di luar siswa. Stimulasi yang diberikan akan melahirkan respons berupa penggunaan bahasa sasaran yang tepat. ${ }^{11}$ Beberapa faktor yang mempengaruhi pemerolehan bahasa yaitu faktor biologis, faktor lingkungan sosial, intelegensi dan motivasi. Secara biologis manusia sejak lahir memiliki potensi berbahasa yang dapat dikembangkan dengan peran lingkungan sekitar. Lingkungan yang dimaksud adalah stimulasi yang diberikan kepada siswa berupa contoh atau model berbahasa. Pemerolehan bahasa bisa berkembang dengan baik juga didukung oleh tingkat intelegensi yang normal. Selain itu, motivasi juga berperan penting dalam mengembangkan pemerolehan bahasa pada siswa, baik motivasi intrinsik maupun ekstrinsik. ${ }^{12}$

Pemerolehan bahasa merupakan proses kognitif yang menjadi dasar seseorang menggunakan bahasa. Proses kognitif yang berlangsung saat seseorang berbicara dan mendengarkan adalah proses mengingat apa yang didengar, identifikasi makna apa yang didengar, berpikir, serta mengemukakan apa yang tersimpan dalam ingatan. ${ }^{13}$ Belajar bahasa kedua sangat tergantung pada perkembangan kognitif siswa dan kompleksitas bahasa yang dipelajari. Hal ini bermakna ketika siswa

${ }^{9}$ Alif Cahya Setiyadi dan Mohammad Syam'un Salim, "Pemerolehan Bahasa Kedua Menurut Stephen Krashen," At-Ta'dib 8, no. 2 (2013), https://ejournal.unida.gontor.ac.id/index.php/tadib/article/view/504.

${ }^{10}$ Shafruddin Tajuddin, "Pengembangan Model Pembelajaran Bahasa Arab Tingkat Sekolah Dasar untuk Meningkatkan Kemampuan Berbahasa Arab Siswa," Parameter: Jurnal Pendidikan Universitas Negeri Jakarta 29, no. 2 (2017): 200-215,

https://doi.org/10.21009/parameter.292.08.

${ }^{11}$ Ahmad Habibi Syahid, "Bahasa Arab Sebagai Bahasa Kedua (Kajian Teoretis Pemerolehan Bahasa Arab Pada Siswa Non-Native)," Arabiyat : Jurnal Pendidikan Bahasa Arab dan Kebahasaaraban 2, no. 1 (2015): 86-97, https://doi.org/10.15408/a.v2i1.1797.

12 Enjang Burhanudin Yusuf, "Perkembangan dan Pemerolehan Bahasa Anak,"

Yinyang: Jurnal Studi Islam Gender dan Anak 11, no. 1 (2016), http://ejournal.iainpurwokerto.ac.id/index.php/yinyang/article/view/826.

${ }^{13}$ Tisa Maharani dan Endang Setiyo Astuti, "Pemerolehan Bahasa Kedua dan Pengajaran Bahasa dalam Pembelajaran BIPA," Jurnal Bahasa Lingua Scientia 10, no. 1 (2018): 121-42, https://doi.org/10.21274/ls.2018.10.1.121-142. 
mendapatkan bahasa dari luar dirinya, ia akan memproses bahasa itu dengan berpikir tentang maknanya tanpa memperhatikan struktur kaidah bahasa yang kemudian menjadi output berbahasa. ${ }^{14}$

\section{Lingkungan Berbahasa}

Lingkungan berbahasa adalah semua yang dilihat, didengar dan dirasakan oleh siswa berkaitan dengan bahasa target yang sedang dipelajari. Lingkungan bahasa Arab di Indonesia sengaja dibentuk sebagai sarana untuk siswa berkomunikasi dengan bahasa sasaran atau target. ${ }^{15}$ Lingkungan berbahasa Arab adalah sebuah masyarakat yang di dalamnya terdapat bermacam-macam kegiatan bahasa Arab, baik itu percakapan sehari-hari ataupun kegiatan bahasa yang lain, seperti: latihan berpidato, seminar, lomba-lomba bahasa, permainan bahasa, dan kegiatan terikat lainnya. ${ }^{16}$ Lingkungan berbahasa merupakan faktor penting bagi pembelajar bahasa guna menguasai bahasa sasaran atau target. Lingkungan bahasa berpengaruh bagi siswa bahasa dalam menghasilkan kemampuan berbahasa yang baik secara personal dan komunal karena setiap individu dapat belajar dan menyerap kebahasaan dalam komunitasnya, kualitas lingkungan berbahasa merupakan sesuatu yang sangat penting bagi keberhasilan siswa dalam mempelajari bahasa.

Lingkungan berbahasa dibagi menjadi dua, yaitu lingkungan non formal dan lingkungan formal. Lingkungan formal adalah lingkungan yang dibentuk secara resmi dan terencana, lingkungan dalam belajar bahasa yang memfokuskan pada penguasaan kaidah-kaidah bahasa yang sedang dipelajari secara sadar. Lingkungan formal tidak terbatas pada kelas karena hal utama dalam lingkungan formal ini para siswa dapat secara sadar mengetahui kaidah-kaidah bahasa yang dipelajari baik dari guru di dalam kelas, dari buku-buku, maupun dari orang lain di luar kelas. ${ }^{17}$ Dengan kata lain, pada lingkungan formal pembelajar bahasa diarahkan untuk menguasai gramatika bahasa. Lingkungan non formal adalah segala hal yang didengar dan diamati oleh siswa secara natural. Lingkungan non formal ini pada hakikatnya terjadi tanpa rekayasa dan

${ }^{14}$ Ahmad Muradi, “Pemerolehan Bahasa Dalam Perspektif Psikolinguistik Dan Alquran," Tarbiyah : Jurnal Ilmiah Kependidikan 7, no. 2 (2018), https://doi.org/10.18592/tarbiyah.v7i2.2245.

${ }^{15}$ Habibah, "Lingkungan Artifisial dalam Pembelajaran Bahasa Arab."

${ }^{16}$ Muh Rasmi, "Kontribusi Language Advisory Council (LAC) terhadap Penciptaan Lingkungan Bahasa Arab di Pondok Pesantren Darul Huffadh Tuju-tuju Kajuara Kabupaten Bone" (Tesis, Universitas Islam Negeri Alauddin Makassar, 2015), http://repositori.uinalauddin.ac.id/1740/.

${ }^{17}$ Lutfi Ulfah Faridah, "Pengenalan Bahasa Arab Untuk Anak Sejak Dini," Prosiding Konfererensi Nasional Bahasa Arab 3, no. 3 (2017): 411-19, http://prosiding.arabum.com/index.php/konasbara/article/view/151. 
pembentukan tidak terencana. Proses pembelajarannya tanpa disadari siswa, bahasa target digunakan oleh seluruh komunitas di lingkungannya, baik itu di jalan, di pasar, di rumah, di sekolah dan sebagainya. Lingkungan non formal terjadi secara alami dan frekuensinya lebih besar daripada lingkungan formal, lingkungan non formal juga lebih banyak berperan jika dibandingkan dengan lingkungan formal dalam hal pemerolehan maupun pembelajaran bahasa. ${ }^{18}$

Dalam menciptakan lingkungan non formal dibutuhkan waktu yang cukup lama dibandingkan lingkungan formal. Lingkungan non formal terdiri dari beberapa macam: Pertama, Lingkungan Psikologis, lingkungan ini dibentuk dengan cara memberikan pengetahuan kepada siswa tentang berbagai urgensi belajar bahasa Arab, manfaat memahami bahasa Arab dalam penerapannya di kehidupan sehari-hari sebagai umat islam, serta membangun persepsi bahwa belajar bahasa Arab sangat mudah dan menyenangkan. Hal ini dilakukan dengan tujuan memberi motivasi kepada siswa, sehingga mereka memiliki antusiasme yang tinggi untuk belajar bahasa Arab. Kedua, Lingkungan Bicara, pengajar sebagai native speaker (nâthiq bi al-lughah al-'Arabiyyah) harus mengoptimalkan fungsi dan peran dengan cara berinteraksi dan berkomunikasi menggunakan bahasa Arab kepada siswa. Proses pembelajaran berlangsung menggunakan bahasa Arab, bertanya, memberikan arahan dan larangan menggunakan bahasa Arab dan percakapan sehari-hari juga berbahasa Arab. Mengadakan "Pekan Arabi" dan memberikan sanksi edukasi pada siswa yang tidak menggunakan bahasa Arab pada saat kewajiban berbahasa telah diterapkan. Membudayakan ungkapan sederhana bahasa Arab dalam kegiatan sehari-hari, seperti mabruk, ahlan wa sahlan dan sebagainya. Karena pada dasarnya bahasa adalah kebiasaan yang berulang-ulang, penerapan terus-menerus dan konsisten. Ketiga, Lingkungan Pandang/Baca, lingkungan pandang/baca dibentuk dengan cara memberikan pengumuman tertulis berbahasa Arab, menamai tempattempat dengan bahasa Arab, contohnya ruangan dapur ditulis "al matbakh", kamar mandi ditulis "hammamun", tanda tanda larangan dan perintah ditulis berbahasa Arab di tempat yang strategis, contohnya "laa tajlis 'alal maktab" dan sebagainya, kata kata mutiara berbahasa Arab serta papan pengumuman berisi daftar mufradat atau kosakata berbahasa Arab yang ditulis dan diperbaharui setiap hari. Keempat, Lingkungan Dengar, pengajar memberikan instruksi berbahasa Arab, seluruh informasi dibacakan dengan berbahasa Arab menggunakan media

\footnotetext{
${ }^{18}$ Andiopenta Purba, “Peranan Lingkungan Bahasa Dalam Pemerolehan Bahasa Kedua," Pena : Jurnal Pendidikan Bahasa Dan Sastra 2, no. 2 (2013), https://onlinejournal.unja.ac.id/pena/article/view/1447.
} 
pengeras suara di setiap kamar siswa asrama, tausiyah setelah sholat berjamaah di masjid berbahasa Arab, pemutaran lagu berbahasa Arab menggunakan media audio lingual, menyetel siaran radio berbahasa Arab dan sebagainya. Kelima, Lingkungan Pandang Dengar, lingkungan ini adalah gabungan dari lingkungan pandang dan lingkungan dengar. Pelaksanaan pembelajaran bahasa Arab dalam penerapan lingkungan ini dapat dilaksanakan dengan pemutaran video edukasi berbahasa Arab, film berbahasa Arab dan siaran berita berbahasa Arab dari penutur aslinya. ${ }^{19}$

\section{Metode Penelitian}

Penelitian ini bertujuan menganalisis Strategi Pembentukan Lingkungan Berbahasa di Madrasah Aliyah, karena pembentukan lingkungan berbahasa merupakan strategi yang sangat penting dalam pemerolehan dan penguasaan bahasa Arab. Tempat penelitian ini adalah Asrama Madrasah Aliyah Negeri 1 Metro Lampung. Pemilihan Madrasah ini didasarkan pertimbangan bahwa Madrasah ini memiliki keunggulan program belajar bahasa Arab di luar jam pelajaran sekolah, yaitu di asrama. Kegiatan kebahasaan yang dilaksanakan di asrama di antaranya : muhadatsah yaumiyah, muhadharah, ilqo' mufradat di pagi hari, lomba pidato bahasa Arab, debat berbahasa Arab dan juga seminar bahasa Arab oleh penutur asli. Selain itu Madrasah ini juga memiliki sarana dan prasarana yang memadai, seperti laboratorium bahasa, media pembelajaran berupa audio dan audio visual. Seluruh sarana dan prasarana tersebut tentu sangat mendukung proses pembentukan lingkungan berbahasa yang kondusif di asrama Madrasah Aliyah Negeri 1 Metro.

Jenis penelitian yang digunakan adalah penelitian kualitatif deskriptif. Peneliti memilih metode ini dikarenakan data-data yang diperoleh peneliti di lapangan dinyatakan dalam bentuk verbal dan dalam analisis deskriptif tanpa menggunakan data statistik. Penelitian ditujukan untuk mendeskripsikan dan menggambarkan fenomena-fenomena yang ada, baik bersifat alamiah maupun rekayasa manusia. Penelitian deskriptif ini tidak memberikan perlakuan, manipulasi atau pengubahan pada variabel-variabel yang diteliti, melainkan menggambarkan suatu kondisi yang apa adanya, bagaimana proses berlangsung, hal-hal apa saja yang menjadi kendala dalam proses pembentukan lingkungan berbahasa. Penelitian ini dilakukan dengan sudut pandang induktif, peneliti terjun ke lapangan terlebih dahulu untuk mengidentifikasi masalah yang diteliti. Kemudian peneliti melakukan penelitian lebih lanjut serta mengumpulkan data yang berkaitan dengan pembentukan lingkungan berbahasa di antaranya kegiatan-kegiatan berbahasa, sarana dan prasarana yang mendukung proses pembentukan

${ }^{19}$ Neli Putri, “Bi'ah 'Arabiyah,” Al-Ta lim Journal 20, no. 2 (2013): 407, https://doi.org/10.15548/jt.v20i2.37. 
lingkungan berbahasa dan respons seluruh pihak yang terlibat dalam pembentukan lingkungan berbahasa di asrama. Dengan pendekatan induktif ini penelitian tidak dipengaruhi oleh konsep atau pandangan sebelumnya dan membuka peluang bagi peneliti untuk melakukan penemuan atau discovery.

Responden penelitian ini adalah siswa asrama Madrasah Aliyah Negeri 1 Metro kelas X, XI dan XII yang berjumlah 170 siswa perempuan dan 73 siswa laki-laki. Seluruh siswa ini berlatar belakang dari Sekolah Menengah Pertama maupun Madrasah Tsanawiyah. Kemampuan berbahasa arab mereka beragam, sebagian dari mereka mengerti kosakata bahasa Arab tetapi tidak mampu mengolahnya menjadi kalimat yang sempurna.

Teknik pengumpulan data yang digunakan oleh peneliti adalah observasi dan wawancara. Observasi dan wawancara digunakan untuk mengumpulkan data tentang bagaimana model-model pembentukan lingkungan berbahasa untuk meningkatkan kemampuan berbahasa siswa Madrasah Aliyah. Peneliti melaksanakan observasi partisipan, pada observasi ini peneliti terlibat langsung dengan kegiatan sehari-hari individu atau kelompok yang diteliti sebagai sumber data penelitian. Hal ini dilakukan oleh peneliti untuk mendapatkan data tentang pembentukan lingkungan bahasa di Madrasah Aliyah Negeri 1 Metro secara lebih mendalam dari berbagai aspek, baik itu dari aktivitas kebahasaan, proses pelaksanaan, penerapan sanksi, kebijakan pengurus serta kemampuan para siswa dalam berbahasa Arab. Dengan langkah observasi ini peneliti lebih mampu memahami konteks data dalam seluruh situasi sosial. Selain itu, wawancara juga dilakukan untuk mengumpulkan data dengan mengemukakan pertanyaan secara langsung atau sepihak kepada responden. Wawancara ini dilakukan untuk menggali keterangan yang lebih mendalam berupa pendapat, kesan, pengalaman pikiran dan sebagainya, mengenai lingkungan bahasa yang ada di asrama.

Teknik analisis dan pengolahan data model Miles dan Huberman yang melalui tahapan berikut: Pertama, Mengumpulkan Data (data collection), sebelum memasuki tahap analisis data, peneliti terlebih dahulu mengecek dan memeriksa kembali data-data yang didapatkan di lapangan yaitu hasil observasi dan wawancara. Kedua, Reduksi Data (data reduction), pada tahap ini, peneliti memilih data yang relevan dengan penelitian dan data yang tidak relevan dengan penelitian ini, data yang relevan akan langsung dianalisis, sedangkan data yang tidak relevan akan disisihkan atau tidak dianalisis. Data yang telah diperoleh ditulis dalam bentuk laporan atau data yang terperinci. Laporan yang disusun berdasarkan data yang diperoleh direduksi, dirangkum, dipilih hal-hal pokok, difokuskan pada yang penting. Data hasil diklasifikasikan berdasarkan satuan konsep, tema, dan kategori tertentu sehingga memberikan gambaran yang lebih tajam tentang hasil pengamatan juga mempermudah peneliti untuk mencari kembali data sebagai tambahan atas data sebelumnya yang diperoleh jika diperlukan. Ketiga, Penyajian Data 
(data display), setelah direduksi peneliti melakukan penyajian data meliputi: identifikasi, klasifikasi atau dikategorisasikan menurut pokok permasalahan, penyusunan, penjelasan data secara sistematis, objektif, dan menyeluruh. Keempat, Penyimpulan (conclusion), langkah selanjutnya adalah menyimpulkan dan melakukan verifikasi atas data-data yang sudah diproses berdasarkan kategori dan makna temuan. ${ }^{20}$

\section{Hasil Penelitian}

Pembentukan lingkungan bahasa di asrama Madrasah Aliyah ini berlandaskan tekad dan komitmen pimpinan dan pengajar dalam mewujudkan pembelajaran bahasa Arab yang komunikatif dan menyenangkan. Kompetensi pengajar juga menjadi hal utama dalam membentuk lingkungan berbahasa yang kondusif, karena pengajar berperan sebagai penggerak sekaligus kreator dalam pembentukan lingkungan berbahasa. Sarana prasarana yang memadai seperti laboratorium bahasa, masjid, perpustakaan bahasa, sanggar bahasa, layanan internet dan sebagainya telah tersedia untuk mendukung proses pelaksanaan lingkungan berbahasa dan menyesuaikan kebutuhan global, juga untuk mempersiapkan siswa Madrasah yang kompetitif berlandaskan Al-Qur'an dan berbasis pendidikan teknologi.

Pengelolaan lingkungan berbahasa di asrama ini berkiblat pada sistem pondok pesantren KMI Gontor, Ponorogo. Akan tetapi tidak secara menyeluruh, dikarenakan asrama juga mengikuti kurikulum Madrasah yang sudah ditetapkan. Mekanisme pengelolaan dengan membentuk "markazul lughah" sebagai bagian yang bertugas menjadi pengurus, konsultan sekaligus penggerak di bagian kebahasaan. Strategi yang diterapkan dalam pembentukan lingkungan berbahasa adalah formal dan non formal. Lingkungan berbahasa di Madrasah ini terbukti mampu mempengaruhi kemahiran berbahasa Arab siswa, salah satunya karena sistem wajib bahasa yang diterapkan di asrama tersebut menjadikan siswa mempelajari bahasa Arab secara bertahap dan terus menerus dalam setiap kegiatan sehari-hari. Selain wajib bahasa, pengawasan dan penguatan yang tepat dari pengajar dan penggerak bahasa merupakan salah satu faktor lingkungan berbahasa yang diterapkan di asrama ini berhasil memahirkan siswa berbicara bahasa Arab. Stimulus yang diberikan oleh para pengajar kepada siswa dalam menciptakan lingkungan berbahasa kemudian direspons oleh siswa dengan tertib menggunakan bahasa Arab dalam percakapan sehari-hari. Berbagai kegiatan tambahan seperti bimbingan intensif, pemberian motivasi dan perlombaan bahasa juga menambah antusiasme siswa.

${ }^{20}$ Sugiyono, Metode Penelitian Kualitatif (Bandung: Alfabeta, 2018), h. 132-142. 
Pendekatan yang digunakan dalam pembentukan lingkungan berbahasa di Madrasah Aliyah sebagai berikut : Pertama, menekankan strategi interaksionis yang bertumpu pada kegiatan komunikatif dan tidak terfokus pada penjelasan kaidah-kaidah yang berlebih. Kedua, materi yang variatif dengan bahan-bahan otentik sehingga pembelajaran menjadi menarik dan bermakna. Ketiga, menyediakan berbagai input kebahasaan sebagai tugas bagi siswa baik media tulis, audio maupun audio visual. Keempat, mewajibkan seluruh siswa untuk aktif berkomunikasi dan pengajar berperan sebagai direktur dan fasilitator. Kelima, menyelenggarakan kegiatan penunjang seperti insya' harian, pidato mingguan, kelompok wawancara dan kelompok pecinta bahasa lainnya. Keenam, menyediakan "sanggar bahasa" yang dibimbing oleh pengurus bahasa dengan menyediakan sarana belajar bahasa sehingga siswa dapat mengakses berbagai pengetahuan kebahasaan secara mandiri.

Lingkungan berbahasa Arab yang dibentuk di asrama Madrasah Aliyah Negeri 1 Metro dengan tekad membangun citra positif pada pembelajaran bahasa Arab yang sering dianggap sulit oleh para siswa, hal ini dilakukan karena lingkungan berbahasa Arab yang ideal adalah lingkungan yang mampu memberikan pengajaran bahasa dengan tanpa disadari oleh siswa sehingga mereka merasa nyaman dan tidak tertekan dalam proses pembelajaran. Kegiatan kebahasaan yang dilaksanakan di asrama cenderung konsisten dan tidak berubah-ubah setiap tahunnya sehingga siswa cukup mengikuti alur kegiatan yang ada. Program lomba kebahasaan di asrama juga dilaksanakan untuk melatih mental siswa dalam hal kemampuan berbicara di depan khalayak ramai. Lingkungan berbahasa juga dapat mengasah bakat dan kreativitas siswa dalam kemahiran berbicara maupun kemahiran lainnya. Mentradisikan semacam reward dan punishment kepada siswa dalam prestasi dan pelanggaran di lingkungan berbahasa dapat mendorong motivasi untuk terus meningkatkan kemampuan mereka dalam berbahasa Arab.

Model-model pembentukan lingkungan berbahasa di asrama Madrasah Aliyah Negeri 1 Metro di antaranya sebagai berikut : Pertama, Lingkungan non sosial, lingkungan ini berupa gedung asrama, masjid, kelas belajar, kamar pengurus, kantor, laboratorium, kantin, puskesmas asrama, lapangan dan tempat-tempat yang ada di seluruh wilayah asrama diberi nama menggunakan bahasa Arab, dimaksudkan agar para siswa dapat melihat dan terbiasa untuk melafalkannya. Sebagai contoh, di pintu kamar pengurus tertulis "hujrotul mudabbir", kantin bertuliskan "maqsof", kantor "diwan" dan sebagainya. Tanda perintah dan larangan juga ditulis dengan berbahasa Arab misalnya "laa takallam illa billughotil'arabiyah", "laa taghsob" di tempat-tempat yang strategis, Kedua, Lingkungan sosial, adalah semua pihak-pihak yang terlibat dalam pembentukan lingkungan bahasa, mulai dari pimpinan asrama, pengurus, staf pengajar dan siswa semua wajib 
menggunakan bahasa Arab. Ketiga, Lingkungan Formal, bentuk lingkungan formal dilakukan dengan pemberian mufradat, pelatihan imla', insya', muhadatsah yaumiyah, pengajaran kaidah-kaidah nahwu dan sharaf dan sebagainya. Keempat, Lingkungan non formal, penciptaan lingkungan non formal adalah tujuan utama pembentukan lingkungan berbahasa yaitu terwujudnya lingkungan bicara menggunakan bahasa Arab oleh seluruh pihak di lingkungan berbahasa. Memberikan informasi dengan berbahasa Arab, slogan-slogan dan karya tulis berbahasa Arab yang dipublikasikan kepada para siswa, serta pemutaran lagu-lagu berbahasa Arab.

Pembentukan lingkungan berbahasa yang diupayakan oleh asrama Madrasah Aliyah Negeri 1 Metro dilakukan dengan cara: Pertama, mewajibkan penggunaan bahasa Arab secara terus-menerus dan berulangulang sehingga membentuk sebuah kebiasaan menggunakan bahasa Arab dalam setiap kegiatan yang ada di asrama,baik pada saat pembelajaran bahasa Arab, saat beraktivitas harian di asrama, di masjid,di lapangan dan di seluruh tempat yang menjadi kawasan lingkungan berbahasa. Latihan menggunakan bahasa Arab secara berulang-ulang akan membantu meningkatkan kemahiran siswa dalam berbahasa Arab. Kedua, asrama mengadakan pekan bahasa, dua pekan berbahasa Arab dan dua pekan berikutnya berbahasa Inggris. Kewajiban ini diberlakukan untuk semua pihak pengajar dan siswa yang ada di asrama, dan apabila ada siswa yang melanggar bahasa atau tidak menggunakan bahasa yang telah ditetapkan maka akan diberi sanksi oleh penggerak bahasa. Ketiga, diadakannya kegiatan ilqa al-mufradat (memberikan kosakata) untuk para siswa usai shalat subuh setiap hari, diawali dengan pengucapan dari pengajar, kemudian siswa mengikuti apa yang diucapkan pengajar, dan menuliskannya di buku masing-masing lalu mereka diwajibkan menghafal mufradat baru tersebut beserta penggunaannya dalam contoh kalimat sempurna. Keempat, pada hari Rabu dan Ahad pagi, para siswa asrama melakukan muhadasah (percakapan) antar siswa dan pengajar dengan menggunakan bahasa Arab sebelum mereka berolahraga di lapangan asrama. Kelima, latihan menulis juga diadakan setiap hari Ahad setelah shalat dhuha, agar para siswa asrama dapat mengasah ide dan gagasan mereka dalam bentuk karya tulis sederhana. Keenam, evaluasi dan sanksi diberikan kepada siswa setiap harinya dengan menerapkan jasus (mata-mata) yang mengawasi setiap siswa yang didapati melanggar bahasa. Nama mereka akan disebutkan saat setelah ceramah sholat magrib di mimbar masjid, kemudian mereka harus menuju "mahkamah lughah", tujuannya agar mendapat sanksi sosial dan sanksi edukasi sehingga mereka berusaha untuk selalu menggunakan bahasa Arab.

Pengajaran kosakata (mufradat) sehari-hari disusun dalam sebuah kalimat sederhana. Siswa juga ditugaskan untuk menambahkan kosakata secara mandiri dan akan dievaluasi setiap satu pekan dalam hal pengucapan, 
penyusunan kalimat dan penulisan yang benar. Keterampilan sosial juga diajarkan kepada siswa, agar mereka mampu beradaptasi dan berinteraksi dengan lingkungan, mempelajari bahasa Arab dari seluruh komponenkomponen yang ada di sekitarnya. Pada tingkat selanjutnya siswa dilatih untuk melakukan percakapan menggunakan bahasa Arab secara bertahap, percakapan sederhana yang dipimpin oleh pengajar dengan tema tertentu. Pelatihan keterampilan vokal dan mental dengan percakapan sangat efektif untuk mewujudkan pembentukan lingkungan berbahasa yang kondusif.

Dalam kegiatan muhadatsah para siswa tidak dituntut untuk menuturkan bahasa Arab dengan kaidah-kaidah yang rumit, hal ini agar siswa dapat terus berlatih berkomunikasi dengan bahasa Arab tanpa khawatir akan kesalahan kaidahnya. Pengajar juga harus bersabar untuk tidak terburu-buru memberikan evaluasi setiap kali siswa melakukan kesalahan dalam penuturan. Partisipasi seluruh komunitas di lingkungan berbahasa terpantau dan terarahkan dengan baik dalam kegiatan pembelajaran bahasa. Siswa diberikan kesempatan yang luas untuk berkomunikasi efektif dengan lingkungan bahasanya dalam berbagai aktivitas Siswa juga tetap berada di bawah pengawasan para pengajar, siswa harus mengutamakan sikap patuh dan taat peraturan yang berlaku seperti wajib bahasa, latihan pidato, pemberian kosakata, latihan percakapan dan latihan menulis. Penyediaan sarana dan media pembelajaran bahasa Arab di asrama Madrasah Aliyah Negeri Metro juga telah memadai, seperti: laboratorium bahasa, layanan internet untuk mengakses siaran dari beberapa negara di Timur Tengah, seperti: siaran al-Jazeera, alArabiyya, al-Manar, dan laininya. Sarana perpustakaan juga dilengkapi dengan koran, majalah, buku dan kamus berbahasa Arab. Peningkatan kerja sama, baik internal antara pimpinan, pengurus, staf pengajar, siswa dan masyarakat sekitar, juga dilakukan agar pembentukan lingkungan berbahasa terus berkembang secara signifikan.

Penelitian ini terfokus pada analisis secara deskriptif tentang strategi, model dan pelaksanaan lingkungan berbahasa dalam meningkatkan kemampuan berbahasa siswa di Madrasah Aliyah. Hasil analisis yang dilakukan peneliti pada keberhasilan pembentukan lingkungan bahasa di Asrama berdasarkan konteks, input, proses dan produk dapat dikategorikan "baik". Hal ini dibuktikan dengan mampunya para pengurus bahasa melaksanakan program kebahasaan, antusiasme yang tinggi dari siswa, tercapainya tujuan pembelajaran bahasa Arab serta prestasi siswa dalam bidang kebahasaan baik di dalam maupun di luar Madrasah. Keberhasilan ini tidak terlepas dari komitmen dan kerja keras seluruh pihak dalam menciptakan lingkungan berbahasa yang kondusif. Semua pihak yang ada di asrama mempunyai visi, misi, dan kepedulian yang sama dalam mewujudkan pembentukan lingkungan berbahasa Arab, proses penciptaan menjadi program yang menuntut upaya kolektif dan kreatif dalam realisasinya. 
Hasil penelitian yang dilakukan peneliti di asrama Madrasah Aliyah Negeri 1 Metro menunjukkan bahwa pembelajaran bahasa Arab dengan menghidupkan suasana lingkungan merupakan cara yang tepat dan cepat dalam mencapai hasil pembelajaran bahasa. Pendekatan lingkungan merupakan suatu pendekatan pembelajaran yang berusaha untuk meningkatkan keterlibatan siswa melalui pendayagunaan lingkungan sebagai sumber belajar. Kegiatan pembelajaran akan menarik perhatian siswa, jika apa yang dipelajari diangkat dari lingkungan, sehingga apa yang dipelajari berhubungan dengan kehidupan dan berfaedah bagi lingkungannya. Salah satu kendala dalam penciptaan lingkungan berbahasa adalah sikap konsisten dari komunitas bahasa itu sendiri. Karena itu, diperlukan sebuah sistem yang variatif dan kreatif yang memungkinkan satu sama lain mengontrol dan membudayakan penggunaan bahasa Arab secara aktif.

Keberhasilan pembentukan lingkungan berbahasa untuk meningkatkan kemampuan berbahasa terbukti dengan kompetensi siswa asrama Madrasah Aliyah Negeri 1 Metro dalam kemahiran berbicara bahasa Arab dengan baik. Kemahiran berbicara merupakan aspek utama dalam pembelajaran bahasa asing, Sebagian besar ahli juga menafsirkan bahwa keterampilan berbicara merupakan tujuan utama dari program pembelajaran bahasa Asing. ${ }^{21}$ Bentukbentuk tes kemampuan berbicara yang dipilih juga bersifat fungsional. Siswa bukan hanya dapat mengungkapkan kemampuan berbahasa, tetapi harus bisa mengungkapkan gagasan, ide, pendapat, perasaan, dan pikirannya menggunakan bahasa Arab. Tes kemampuan berbicara menuntut siswa menunjukkan kemampuan dan penguasaannya terhadap beberapa aspek dan kaidah penggunaan bahasa yang diungkapkan secara lisan. Bentuk-bentuk tes kemampuan berbicara yang dilakukan di asrama Madrasah Aliyah Negeri 1 Metro dapat berbentuk wawancara, bercerita, pidato, istinbath dan diskusi.

\section{E. Pembahasan}

Lingkungan berbahasa sangat mendukung proses penguasaan bahasa Arab di Madrasah Aliyah. Sebuah teori menyebutkan bahwa pembentukan lingkungan berbahasa mampu meningkatkan kemahiran berbahasa siswa bahasa. ${ }^{22}$ Lingkungan berbahasa menjadi media pembelajaran bahasa yang variatif, inovatif dan menyenangkan, karena proses pembelajaran bahasa Arab yang berlangsung di dalam lingkungan berbahasa tidak hanya terjadi di dalam kelas dan tidak terfokus pada kaidah-kaidah bahasa Arab saja, akan

${ }^{21}$ Umi Hanifah, "Pengembangan Literasi Berbicara Bahasa Arab (Mahārat AlKalām) Di Madrasah Ibtidaiyah (MI)," Elementary: Islamic Teacher Journal 6, no. 2 (2018): 206, https://journal.iainkudus.ac.id/index.php/elementary/article/view/4383.

22 Hidayat, "Bi'ah Lughowiyah (Lingkungan Berbahasa) Dan Pemerolehan Bahasa (Tinjauan Tentang Urgensi Lingkungan Berbahasa Dalam Pemerolehan Bahasa)." 
tetapi seluruh unsur materiil dan immateriil yang berada di sekitarnya menjadi sumber belajar bahasa bagi siswa. Metode pembelajaran yang melibatkan seluruh aspek dan pihak tersebut membuat siswa aktif dan antusias dalam proses pembelajaran bahasa.

Berkembang dari penelitian sebelumnya tentang lingkungan dengar yang bertujuan untuk meningkatkan kemampuan berbicara siswa bahasa. ${ }^{23}$ Model pembentukan lingkungan berbahasa yang diterapkan di asrama Madrasah Aliyah Negeri 1 Metro direalisasikan dengan menerapkan lingkungan pandang, lingkungan dengar, lingkungan pandang dengar sehingga siswa akan mendapatkan input bahasa dari apa yang ia dengar, lihat, pikirkan, perhatikan dan dirasakan secara berulang-ulang selama berada di lingkungan berbahasa. Setiap ungkapan, pengumuman, larangan dan instruksi berbahasa Arab yang diberikan oleh pengajar serta interaksi antara siswa dengan anggotanya di lingkungan berbahasa juga akan menjadi stimulus bagi siswa dalam belajar dan mengaplikasikan bahasa Arab seharihari. ${ }^{24}$ Kegiatan kebahasaan yang beragam dan pembelajaran bahasa Arab yang berlangsung secara optimal di lingkungan berbahasa mampu melatih kemahiran siswa dalam aspek kebahasaan, hal ini menunjukkan bahwa lingkungan berbahasa sangat mendukung proses penguasaan bahasa Arab.

Sesuai dengan sistem pembelajaran kurikulum 2013 yang menerapkan model pembelajaran langsung atau lebih dikenal dengan active learning maka pembentukan lingkungan berbahasa di Madrasah Aliyah ini bertujuan menekankan pembelajaran yang melibatkan keaktifan siswa dalam mengamati, bertanya, menganalisis dan mengkomunikasikan hasil pembelajaran yang telah mereka peroleh. ${ }^{25}$

Lingkungan berbahasa juga menjadi sarana pemberdayagunaan bahasa Arab secara komunikatif melalui pelaksanaan kegiatan muhadatsah yaumiyah, muhadharah, debat dan seminar bahasa Arab. Bahasa secara fungsional adalah sebagai alat komunikasi manusia dalam penyampaian ide, gagasan dan interaksi antar sesamanya, maka salah satu tujuan dari pembelajaran bahasa Arab adalah mampu berkomunikasi, menyampaikan ide dan gagasan menggunakan bahasa Arab dengan lancar. Indikasi dari seorang siswa yang telah dianggap menguasai bahasa terbukti bahwa secara verbal ia mampu berbicara menggunakan bahasa Arab dan memahami makna bahasa tersebut dengan baik. Pada dasarnya pendekatan komunikatif ini merupakan

\footnotetext{
${ }^{23}$ Maspalah, “Metode Audiolingual Dalam Pembelajaran Bahasa Arab Untuk Meningkatkan Kemampuan Berbicara."

${ }^{24}$ Ahmad Fuad Effendy, Metodologi Pengajaran Bahasa Arab (Malang: Misykat, 2017), h. 226-229.

${ }^{25}$ Miftahur Rohman, "Pembelajaran Bahasa Arab Di Madrasah Aliyah Dalam Perspektif Kurikulum 2013," An Nabighoh: Jurnal Pendidikan Dan Pembelajaran Bahasa Arab 20, no. 02 (2018): 222, https://doi.org/10.32332/an-nabighoh.v20i02.1286.
} 
pendekatan pembelajaran bahasa yang lebih menekankan pembelajaran pada penguasaan kecakapan berbahasa daripada penguasaan struktur bahasa. ${ }^{26}$

Sarana prasarana pembelajaran yang memadai, pengajar sebagai penggerak bahasa yang profesional dan ghirah (minat) siswa bahasa Arab yang tinggi belum tentu menjamin keberhasilan mencapai tujuan tersebut jika lingkungan tidak mendukung terjadinya dialog intensif antara siswa dengan pengajar maupun dengan sesamanya. Praktek muhadatsah yaumiyah yang diterapkan di lingkungan berbahasa dapat mewujudkan komunikasi antara pembicara dan pendengar secara spontan. Praktek ini juga dapat mengembangkan kemampuan siswa dalam mengidentifikasi dan mengasosiasikan makna bahasa yang ia dengar untuk segera direspons. Komunikasi timbal balik antara pendengar dan pembicara di dalam lingkungan berbahasa ini terjadi secara langsung dan terus menerus di dalam lingkungan berbahasa dengan konsekuensi bagi siswa yang tidak berbicara menggunakan bahasa Arab akan diberikan sanksi. Kegiatan muhadatsah dilaksanakan dengan beberapa tahapan yaitu : pemula, menengah dan lanjutan. Tahap pemula siswa dilatih pola percakapan sederhana dengan pembahasan yang ringan seperti kegiatan sehari-hari dan sebagainya. Tahap menengah topik percakapan semakin luas, siswa dapat mengidentifikasi makna bahasa yang ia dengar secara mandiri untuk langsung merespons lawan bicara. Tahap lanjutan siswa dianggap telah mahir dalam berbicara bahasa Arab dan pengajar cukup memberikan arahan dan evaluasi. Selain muhadatsah tersebut, kegiatan muhadharah, debat dan seminar yang dilaksanakan di dalam lingkungan berbahasa juga mampu melatih siswa dalam mengasah kemampuan berbicara bahasa Arab di hadapan khalayak ramai sehingga tujuan pemberdayaan bahasa Arab secara komunikatif telah tercapai. Dengan adanya lingkungan berbahasa yang kondusif tersebut, terbukti bahwa lingkungan berbahasa telah memberdayakan bahasa Arab secara komunikatif.

Lingkungan berbahasa memperkuat pembelajaran bahasa Arab yang telah dipelajari dalam kelas, siswa memiliki kesempatan untuk mempraktekkan kemampuan berbahasa Arab yang dimilikinya. Kedudukan lingkungan berbahasa menjadi situasi pendukung yang bersifat semi alamiah seperti proses pemerolehan bahasa. Pembelajaran bahasa Arab yang berlangsung di dalam kelas dengan suasana yang monoton dan durasi yang tidak terlalu lama membuat input bahasa yang didapatkan oleh siswa menjadi terbatas, sedangkan di dalam lingkungan berbahasa segala aktivitas kebahasaan diterapkan dan dilaksanakan setiap hari selama 24 jam,

${ }^{26}$ Muspika Hendri, “Pembelajaran Keterampilan Berbicara Bahasa Arab Melalui Pendekatan Komunkatif," POTENSIA: Jurnal Kependidikan Islam 3, no. 2 (22 Desember 2017): 196-210, https://doi.org/10.24014/potensia.v3i2.3929. 
pembelajaran bahasa Arab juga diberikan dengan berbagai cara melalui lingkungan dengar, lingkungan bicara dan lingkungan pandang/baca. Oleh karena itu, pembelajaran bahasa Arab akan maksimal dan sempurna dengan terciptanya lingkungan berbahasa yang kondusif. Lingkungan berbahasa memberikan pengajaran intensif pada siswa untuk melatih kemampuan berbahasanya secara lisan maupun tulisan. Pembelajaran bahasa Arab di dalam kelas pada umumnya mengutamakan pemahaman-pemahaman kaidah linguistik di antaranya nahwu dan sharaf, praktik bahasa Arab secara komunikatif jarang diterapkan didalam kelas karena pembelajaran mengacu pada kurikulum dan materi yang ditetapkan. Lingkungan berbahasa menjadi wadah bagi siswa dalam mempraktekkan kemampuan berbahasanya terutama kemahiran berbicara. Berbekal pemahaman kaidah bahasa yang dipelajari di dalam kelas, siswa memiliki kesempatan yang sangat besar untuk mengaplikasikan kemahiran bahasa Arab mereka dengan kegiatan kebahasaan yang diterapkan di lingkungan berbahasa dengan maksimal. Mereka dapat menggunakan pemahaman nahwu untuk membuat insya', melatih penguasaan sharaf dengan berdialog bahasa Arab antar sesama sehari-hari dan kegiatan pendukung lainnya. Hal ini menunjukkan bahwa lingkungan berbahasa memperkuat pembelajaran bahasa Arab yang telah dipelajari di dalam kelas.

Lingkungan berbahasa mengoptimalkan kreativitas dan aktivitas bahasa Arab secara sinergis antara teori dan praktek dalam suasana informal dan tidak membosankan. Tersedianya sarana dan prasarana kebahasaan di dalam lingkungan berbahasa seperti laboratorium bahasa, lorong bahasa, perpustakaan bahasa, sanggar bahasa, akan menciptakan suasana berbeda dibandingkan pembelajaran bahasa Arab di dalam kelas. Dengan adanya sarana dan prasarana tersebut siswa dapat menjangkau sumber kebahasaan secara mandiri dengan membaca buku berbahasa Arab, majalah Arab, koran berbahasa Arab, mengikuti siaran radio dan televisi berbahasa Arab, menonton film berbahasa Arab, latihan menulis karangan bahasa Arab, pidato bahasa Arab, wawancara berbahasa Arab dan sebagainya. Berbagai kegiatan yang bernuansa kebahasaan, seperti: diskusi, ceramah (dengan mengundang native speaker atau pakar misalnya), seminar berbahasa Arab, penerbitan majalah dinding juga digalakkan demi mendukung pembentukan lingkungan berbahasa yang kondusif. Penyelenggaraan lomba-lomba berbahasa Arab, seperti: lomba pidato, cerdas cermat, karya tulis, drama, kosakata Arab, debat, dan sebagainya juga dapat meningkatkan motivasi dan minat yang tinggi bagi siswa dalam belajar bahasa Arab, karena optimalisasi motivasi sangat berpengaruh pada pembentukan psikologis siswa yang 
kesulitan dalam belajar bahasa Arab. ${ }^{27}$ Ringkasnya, lingkungan bahasa di asrama Madrasah Aliyah Negeri 1 Metro memberi kesempatan siswa berkreasi dalam melatih kemampuan bahasa mereka serta aktivitas kebahasaan yang beragam mendukung perkembangan kemampuan berbahasa mereka secara signifikan, dengan adanya lingkungan berbahasa proses pembelajaran bahasa Arab menjadi lebih dinamis, efektif dan variatif.

\section{F. Kesimpulan}

Pembentukan lingkungan berbahasa merupakan salah satu upaya yang mendukung dalam proses penguasaan bahasa Arab. Dengan adanya lingkungan berbahasa, kemampuan berbahasa siswa dalam aspek kemahiran bahasa Arab dapat dimaksimalkan. Hasil penelitian di asrama Madrasah Aliyah Negeri 1 Metro yang menerapkan lingkungan berbahasa menunjukkan bahwa lingkungan bahasa berperan aktif dalam peningkatan kemampuan berbahasa Arab para siswa di dalamnya. Model-model pembentukan lingkungan berbahasa di asrama Madrasah Aliyah Negeri 1 Metro di antaranya : Lingkungan non sosial, berupa gedung asrama, masjid, kelas belajar, kamar pengurus, kantor, laboratorium, kantin, puskesmas asrama, lapangan dan tempat-tempat yang ada di seluruh wilayah asrama diberi nama menggunakan bahasa arab, dimaksudkan agar para siswa dapat melihat dan terbiasa untuk melafalkannya. Lingkungan sosial, adalah semua pihak-pihak yang terlibat dalam pembentukan lingkungan bahasa, mulai dari pimpinan asrama, pengurus, staf pengajar dan siswa semua wajib menggunakan bahasa Arab. Lingkungan formal, bentuk lingkungan formal dilakukan dengan pemberian mufradat, pelatihan imla', insya', muhadatsah yaumiyah, pengajaran kaidah-kaidah nahwu dan sharaf dan sebagainya. Lingkungan non formal, penciptaan lingkungan non formal adalah tujuan utama pembentukan lingkungan berbahasa yaitu terwujudnya lingkungan bicara menggunakan bahasa Arab oleh seluruh pihak di lingkungan bahasa. Kegiatan-kegiatan kebahasaan yang beragam dan pembelajaran bahasa Arab yang berlangsung secara optimal di dalam lingkungan berbahasa mampu melatih kemahiran siswa dalam aspek kebahasaan, hal ini menunjukkan bahwa lingkungan berbahasa sangat meningkatkan kemampuan berbahasa siswa Madrasah Aliyah.

\footnotetext{
${ }^{27}$ Muhbib Abdul Wahab, "Revitalisasi Penciptaan Bi'ah Lughawiyyah Dalam Pengembangan Keterampilan Bahasa Arab" (Fakultas IImu Tarbiyah dan Keguruan UIN Syarif Hidayatullah, 2015), http://repository.uinjkt.ac.id/dspace/handle/123456789/28300.
} 


\section{Daftar Pustaka}

Aflisia, Noza, dan Partomuan Harahap. “Eksistensi Bi'ah Lughawiyah Sebagai Media Berbahasa Arab Dalam Meningkatkan Kemampuan Muhadatsah Mahasiswa Prodi Pendidikan Bahasa Arab IAIN Curup." Lisanul' Arab: Journal of Arabic Learning and Teaching 8, no. 1 (2019): 40-55. https://journal.unnes.ac.id/sju/index.php/laa/article/view/32545.

Effendy, Ahmad Fuad. Metodologi Pengajaran Bahasa Arab. Malang: Misykat, 2017.

Faridah, Lutfi Ulfah. "Pengenalan Bahasa Arab Untuk Anak Sejak Dini." Prosiding Konfererensi Nasional Bahasa Arab 3, no. 3 (2017): 411-19. http://prosiding.arab-um.com/index.php/konasbara/article/view/151.

Habibah, Nur. "Lingkungan Artifisial dalam Pembelajaran Bahasa Arab." Arabiyat : Jurnal Pendidikan Bahasa Arab dan Kebahasaaraban 3, no. 2 (2016): 17396. https://doi.org/10.15408/a.v3i2.4038.

Hanifah, Umi. "Pengembangan Literasi Berbicara Bahasa Arab (Mahārat Al-Kalām) Di Madrasah Ibtidaiyah (MI)." Elementary: Islamic Teacher Journal 6, no. 2 (2018): 206.

https://journal.iainkudus.ac.id/index.php/elementary/article/view/4383.

Hendri, Muspika. "Pembelajaran Keterampilan Berbicara Bahasa Arab Melalui Pendekatan Komunkatif." POTENSIA: Jurnal Kependidikan Islam 3, no. 2 (22 Desember 2017): 196-210. https://doi.org/10.24014/potensia.v3i2.3929.

Hidayat, A. "Bi'ah Lughowiyah (Lingkungan Berbahasa) Dan Pemerolehan Bahasa (Tinjauan Tentang Urgensi Lingkungan Berbahasa Dalam Pemerolehan Bahasa)." An-Nida' 37, no. 1 (2012): 35-44. http://ejournal.uinsuska.ac.id/index.php/Anida/article/view/311.

Juniarti, Yenti, dan Eva Gustiana. "Pengembangan Sumber Belajar Bermain Berbasis Mobile Learning." Jurnal Pendidikan Edutama 6, no. 1 (2019): 3742. https://doi.org/10.30734/jpe.v6i1.289.

Khairi, Husnuzziadatul. "Karakteristik Perkembangan Anak Usia Dini Dari 0-6 Tahun." Jurnal Warna 2, no. 2 (2018): 15-28. https://ejournal.iaiig.ac.id/index.php/warna/article/view/87.

Maharani, Tisa, dan Endang Setiyo Astuti. "Pemerolehan Bahasa Kedua dan Pengajaran Bahasa dalam Pembelajaran BIPA." Jurnal Bahasa Lingua Scientia 10, no. 1 (2018): 121-42. https://doi.org/10.21274/ls.2018.10.1.121-142.

Maspalah, Maspalah. "Metode Audiolingual Dalam Pembelajaran Bahasa Arab Untuk Meningkatkan Kemampuan Berbicara." Jurnal Pendidikan Bahasa Dan Sastra 15, no. 1 (2015): 68-78. https://doi.org/10.17509/bs_jpbsp.v15i1.800. 
Muradi, Ahmad. "Pemerolehan Bahasa Dalam Perspektif Psikolinguistik Dan Alquran." Tarbiyah : Jurnal Ilmiah Kependidikan 7, no. 2 (2018). https://doi.org/10.18592/tarbiyah.v7i2.2245.

Purba, Andiopenta. "Peranan Lingkungan Bahasa Dalam Pemerolehan Bahasa Kedua." Pena : Jurnal Pendidikan Bahasa Dan Sastra 2, no. 2 (2013). https://online-journal.unja.ac.id/pena/article/view/1447.

Putri, Neli. “Bi'ah 'Arabiyah.” Al-Ta lim Journal 20, no. 2 (2013): 407. https://doi.org/10.15548/jt.v20i2.37.

Rasmi, Muh. “Kontribusi Language Advisory Council (LAC) terhadap Penciptaan Lingkungan Bahasa Arab di Pondok Pesantren Darul Huffadh Tuju-tuju Kajuara Kabupaten Bone." Tesis, Universitas Islam Negeri Alauddin Makassar, 2015. http://repositori.uin-alauddin.ac.id/1740/.

Rizqi, M. Rizal. "Resonansi Bi'ah Lughawiyyah Dalam Meningkatkan Akuisisi Bahasa Arab." Dar-EL-Ilmi : Jurnal Studi Keagamaan, Pendidikan Dan Humaniora 4, no. 2 (2017): 89-105. http://ejurnal.unisda.ac.id/index.php/dar/article/view/654.

Rohman, Miftahur. "Pembelajaran Bahasa Arab Di Madrasah Aliyah Dalam Perspektif Kurikulum 2013." An Nabighoh: Jurnal Pendidikan Dan Pembelajaran Bahasa Arab 20, no. 02 (2018): 222. https://doi.org/10.32332/an-nabighoh.v20i02.1286.

Salamah, Siti. "Studi Ringkas Pemerolehan Bahasa Pada Anak." BAHASTRA 33, no. 2 (2015). http://journal.uad.ac.id/index.php/BAHASTRA/article/view/2636.

Setiyadi, Alif Cahya, dan Mohammad Syam'un Salim. "Pemerolehan Bahasa Kedua Menurut Stephen Krashen." At-Ta'dib 8, no. 2 (2013).

https://ejournal.unida.gontor.ac.id/index.php/tadib/article/view/504.

Sugiyono. Metode Penelitian Kualitatif. Bandung: Alfabeta, 2018.

Syahid, Ahmad Habibi. "Bahasa Arab Sebagai Bahasa Kedua (Kajian Teoretis Pemerolehan Bahasa Arab Pada Siswa Non-Native)." Arabiyat : Jurnal Pendidikan Bahasa Arab dan Kebahasaaraban 2, no. 1 (2015): 86-97. https://doi.org/10.15408/a.v2i1.1797.

Tajuddin, Shafruddin. "Pengembangan Model Pembelajaran Bahasa Arab Tingkat Sekolah Dasar untuk Meningkatkan Kemampuan Berbahasa Arab Siswa." Parameter: Jurnal Pendidikan Universitas Negeri Jakarta 29, no. 2 (2017): 200-215. https://doi.org/10.21009/parameter.292.08.

Wahab, Muhbib Abdul. "Revitalisasi Penciptaan Bi'ah Lughawiyyah Dalam Pengembangan Keterampilan Bahasa Arab." Fakultas Ilmu Tarbiyah dan Keguruan UIN Syarif Hidayatullah, 2015.

http://repository.uinjkt.ac.id/dspace/handle/123456789/28300.

Yusuf, Enjang Burhanudin. "Perkembangan dan Pemerolehan Bahasa Anak." Yinyang: Jurnal Studi Islam Gender dan Anak 11, no. 1 (2016). http://ejournal.iainpurwokerto.ac.id/index.php/yinyang/article/view/826. 